\title{
Determined and declared nicotine content in refill liquids for electronic cigarettes marketed in North Macedonia
}

\author{
Marija Srbinoska ${ }^{1}$, Zoran Kavrakovski², Vesna Rafajlovska³ ${ }^{3}$, and Jana Simonovska ${ }^{3}$ \\ ${ }^{1}$ Scientific Tobacco Institute Prilep, St. Kliment Ohridski University of Bitola, Prilep, North Macedonia \\ ${ }^{2}$ Faculty of Pharmacy, Ss. Cyril and Methodius University in Skopje, Skopje, North Macedonia \\ ${ }^{3}$ Faculty of Technology and Metallurgy, Ss. Cyril and Methodius University in Skopje, Skopje, North Macedonia
}

[Received in September 2018; Similarity Check in September 2018; Accepted in March 2019]

\begin{abstract}
The use of electronic cigarettes or vaping has been gaining momentum among Macedonian smokers but has also raised great many concerns about the toxicity of liquid refills and its aerosols, especially as the nicotine levels in refill liquids (e-liquids) are not required to be declared accurately or at all by current regulations. The aim of this study was therefore to determine nicotine levels in fifteen samples of e-liquids purchased in specialised shops in Macedonia using gas chromatography. Nicotine concentrations deviated from manufacturer's declarations in nine of the twelve samples: in five they were higher and in four lower than declared, ranging from $-16.7 \%$ to $+30.0 \%$. These significant discrepancies between the actual and declared nicotine concentrations in the analysed e-liquids call for closer attention of the healthcare and the regulating authorities.
\end{abstract}

KEY WORDS: e-liquids; gas chromatography; Tobacco Products Directive; vaping

Electronic cigarettes or e-cigarettes are handheld devices designed to simulate smoking by heating a liquid solution containing propylene glycol, ethylene glycol and/ or glycerine, flavourings, water, ethanol, additives, and often nicotine (1-3). With smoking being banned in enclosed public spaces all over the world, e-cigarettes have soon become a very popular substitute or the means to gradually quit smoking $(4,5)$. With their increasing use new products appear on the market. In 2016 alone, the sales of e-cigarettes and tobacco vapour products were $\$ 11.44$ billion and are expected to reach a double-digit annual growth by 2025 (6).

Manufacturers advertise them as healthier, safer, less expensive, cleaner, and socially accepted alternatives to combustible cigarettes that can be used in enclosed public spaces where smoking is otherwise banned $(5,7)$.

First-generation e-cigarettes were prefilled disposable devices that were designed to look like traditional cigarettes. Second- and third-generation e-cigarettes (vapours, tanks, and mods) have interchangeable parts, including an aerosol generator, a heating element, a refillable tank, and rechargeable batteries.

E-cigarette cartridges, cartomisers, and tanks can now be refilled from drip bottles of refill liquids that can be bought online, by mail orders, and in retail shops. In 2014, Zhu et al. (8) reported 7764 flavours of commercial e-liquids

Corresponding author: Marija Srbinoska, Scientific Tobacco Institute Prilep, St. Kliment Ohridski University of Bitola, Kichevska bb,7500 Prilep, Macedonia; e-mail: srbinoska.marija2014@gmail.com and ready-made refill solutions such as tobacco, menthol, fruits, candies, chewing gum, alcoholic drinks, soft drinks, coffee, and their combinations. Some manufacturers allow consumers to buy "vape juice kit" with ingredients, nicotine solutions, and aromas from which they create their own do-it-yourself (DIY) e-liquids after their preference.

Consumers consider nicotine strength an important factor when purchasing e-liquids, and their preferences usually depend on whether they also smoke tobacco cigarettes or not. E-liquids therefore come in different nicotine concentrations $(0-20 \mathrm{mg} / \mathrm{mL})$ declared on the packaging in milligrams, percentages, or descriptors such as "extra strong/very high", "strong/high", "regular/ medium", "light/low", "ultra-light/very low", or "zero/no nicotine". Studies investigating e-cigarette aerosols report that nicotine levels may vary considerably by brand, product, user puff topography, and device voltage (9-11).

However, the use of these devices has raised several concerns about the toxicity of liquid refills and their aerosols and related adverse health effects $(12,13)$. According to the World Health Organization (14), as long as electronic cigarettes and liquids are not regulated and their impact on human health is not thoroughly investigated, they should not be recommended as an aid to quit smoking. The EU Tobacco Products Directive (15), however, has set the safety maximum level for nicotine to $\leq 20 \mathrm{mg} / \mathrm{mL}$ in e-liquid.

Unregulated marketing and manufacturing standards for e-liquids may result in significant differences between declared and true levels of nicotine in cartridges and refill 
solutions for e-cigarettes. While there are reports of good compliance between nicotine levels declared on e-cigarette cartridges and refill bottles and the measured ones $(16,17)$, some studies have reported significant differences (16-18) or even found high nicotine concentrations in liquids declared nicotine-free (19). The main concern with nicotine in e-cigarettes is whether their use exposes users or bystanders (passive smokers) to the risk of nicotine poisoning. Nicotine is both addictive and toxic in small doses, and it is important that its concentrations are accurately labelled on an e-liquid $(20,21)$ because labelling an e-liquid as containing a low nicotine concentration may mislead a user to consume more nicotine than intended and put themselves at risk of overdosing. Consumers who are misled that they are using a nicotine-free product, in turn, may develop addiction.

As the vaping trend has taken root in Macedonia as well, we wanted to see whether declared nicotine concentrations in locally marketed e-liquids deviated from the actual and whether this might present a public health problem, especially in terms of doses higher than the EU maximum of $20 \mathrm{mg} / \mathrm{mL}$.

\section{MATERIALS AND METHODS}

\section{Samples}

For the purpose of this study, we randomly acquired 15 of $10 \mathrm{~mL}$ e-liquid bottles of four global manufacturers from specialised shops in Macedonia with different nicotine concentrations declared $(0-24 \mathrm{mg} / \mathrm{mL})$. All samples were refill (ready-to-use) liquids, and two packages per sample were tested. On nine of the fifteen e-liquid packages nicotine content was expressed in "mg" and on the rest in $\mathrm{mg} / \mathrm{mL}$. Some of the packages were additionally labelled with descriptors such as "zero", "medium", or "high" that correspond to the declared nicotine concentration.

\section{Chemicals}

For nicotine determination we used dichloromethane (SupraSolv, Merck, Darmstadt, Germany), $99 \%$ n-heptadecane (Sigma-Aldrich Chemie GmbH, Taufkirchen, Germany), and $\geq 99 \%$ purity nicotine standard (SigmaAldrich).

\section{Gas chromatography}

Nicotine concentrations in the e-liquid samples were quantified using the gas chromatographic method described by Schober et al. (19). All samples were analysed after dilution with dichloromethane in the 100:1 (v/v) ratio, followed by the addition of $n$-heptadecane. After dilution, the measured nicotine values were within the concentration range of the calibration curve.

For gas chromatography we used a Hewlett Packard Model 7890B GC (Hewlett Packard, Santa Clara, CA, USA) equipped with an auto-injector module 763A, flame ionisation detector (FID), and a HP-5 column $(30 \mathrm{~m} \times 0.32 \mathrm{~mm} \times 0.25 \mu \mathrm{m})$. The temperature was raised from $140{ }^{\circ} \mathrm{C}$ to $210{ }^{\circ} \mathrm{C}$ at a $20^{\circ} \mathrm{C} / \mathrm{min}$ ramp with a hold time of 25 min using helium as a carrier gas. The temperature of the injector (injection volume $1 \mu \mathrm{L}$ and split ratio $20: 1$ ) and detector was $250^{\circ} \mathrm{C}$.

\section{Nicotine calibration standard}

Nicotine standards used to establish the calibration curve were prepared by serial dilution of $1.0 \mathrm{mg} / \mathrm{mL}$ of nicotine in dichloromethane over a range of $1.0-0.016 \mathrm{mg} /$ $\mathrm{mL}$. For internal standard we used $n$-heptadecane.

\section{Statistical analysis}

Statistical analysis was run on SPSS Statistics version 23, (IBM, New York, NY, USA) using the Wilcoxon signedrank test for dependent samples. The significance level was set at $5 \%(\mathrm{p}<0.05)$.

\section{RESULTS AND DISCUSSION}

Table 1 compares the declared and quantified nicotine concentrations in the fifteen e-liquid products. The differences are expressed in percentages. They deviated from manufacturer labels in nine samples: five had significantly higher and four lower concentrations than declared (range from $-16.7 \%$ to $+30.0 \%$ ).

Our findings confirm other reports about inconsistencies between declared and measured nicotine levels in e-liquids (22-27). Cheng (25) furthermore reported that nicotine delivery was not even consistent between brands or within a brand (between puffs). Farsalinos et al. (26) reported inconsistencies between declared and measured concentrations to range from $-21 \%$ to $+22.1 \%$, whereas in Kim et al. (27) they ranged from $-32.2 \%$ to $+3.3 \%$.

All these findings, including ours, call for regulations that should define uniform standards for declaring nicotine concentrations in refill products, and provide manufacturers and suppliers guidelines not only to adopt them but also to ensure uniform within-device dosing (i.e. the same product should always be consistent in nicotine delivery), appropriate manufacturing standards, and accurate reporting of nicotine content in refill products prior to market release.

Inaccurately declared lower nicotine concentration in e-liquids may mislead consumers into consuming more products and overdosing on nicotine, especially if the declared doses are close to the maximum allowed concentration set by the EU Tobacco Products Directive (15). A case in point is our sample no. 12 (Table 1) with a declaration of $18 \mathrm{mg} / \mathrm{mL}$, whereas the actual concentration was over $20 \mathrm{mg} / \mathrm{mL}$. Furthermore, e-liquid packages declaring nicotine concentrations above the EU safety limit are freely marketed in Macedonia, which raises a red flag for regulators in the country to adopt the EU limit and in 
Table 1 Comparison between declared and measured nicotine concentrations in sampled e-liquids

\begin{tabular}{|c|c|c|c|c|c|}
\hline No. & Flavour & Descriptor & $\begin{array}{c}\text { Declared } \\
\text { concentration } \\
(\mathbf{m g} \text { or } \mathbf{m g} / \mathbf{m L})\end{array}$ & $\begin{array}{c}\text { Measured mean } \\
\text { concentration } \pm \text { SD }^{1} \\
(\mathrm{mg} / \mathrm{mL})\end{array}$ & $\begin{array}{c}\text { Difference in } \\
\text { concentration }(\%)\end{array}$ \\
\hline 1 & L1 Tobacco & Nicotine-free & 0 & $0 \pm 0.2$ & 0 \\
\hline 2 & L2 Strawberry & Zero & 0 & $0 \pm 0.1$ & 0 \\
\hline 3 & L3 Vanilla & Zero & 0 & $0.6 \pm 0.2$ & 0 \\
\hline 4 & L4 Tobacco & I & 6 & $5.4 \pm 0.6$ & $-10^{*}$ \\
\hline 5 & L5 Tobacco & 1 & 6 & $7.8 \pm 0.9$ & $30 *$ \\
\hline 6 & L6 Tobacco & Medium & 9 & $10.8 \pm 1.1$ & $20^{*}$ \\
\hline 7 & L7 Strawberry & Medium & 9 & $10.4 \pm 0.9$ & $15.6^{*}$ \\
\hline 8 & L8 Tobacco & I & 9 & $7.5 \pm 0.8$ & $-16.7 *$ \\
\hline 9 & L9 Vanilla & I & 9 & $9.0 \pm 1.9$ & 0 \\
\hline 10 & L10 Tobacco & Regular & 18 & $21.1 \pm 2.1$ & $17.2^{*}$ \\
\hline 11 & L11 Strawberry & Regular & 18 & $17.9 \pm 2.5$ & -0.6 \\
\hline 12 & L12 Vanilla & 1 & 18 & $20.0 \pm 1.9$ & $11.1^{*}$ \\
\hline 13 & L13 Vanilla & 1 & 18 & $18.0 \pm 1.2$ & 0 \\
\hline 14 & L14 Tobacco & High & 24 & $24.0 \pm 2.1$ & 0 \\
\hline 15 & L15 Vanilla & High & 24 & $24.3 \pm 1.1$ & 1.25 \\
\hline
\end{tabular}

${ }^{1}$ Mean of three measurements \pm standard deviation (SD); ${ }^{*}$ - significant difference from declared concentrations $(p<0.05)$

the meantime require from producers to warn consumers of increased health risk these concentrations entail.

There are several limitations to our study. We selected four top-selling manufacturers instead of analysing products of all available manufacturers on the market, because of laboratory cost. Another limitation is that we analysed only one batch per e-liquid and therefore could not assess interbatch variability. Further research should address these limitations, but even with current limitations our study clearly shows that nicotine-containing refill e-liquid products must meet certain quality standards before marketing, including accurate declaration to prevent unintentional nicotine overdosing.

\section{REFERENCES}

1. Kennedy RD, Awopegba A, de León E, Cohen JE. Global approaches to regulating electronic cigarettes. Tob Control 2017;26:440-5. doi: 10.1136/tobaccocontrol-2016-053179

2. Breland A, Soule E, LopezA,Ramôa C, El-Hellani A, Eissenberg T. Electronic cigarettes: what are they and what do they do? Ann N Y Acad Sci 2017;1394:5-30. doi: 10.1111/ nyas. 12977

3. Chen Z, Zeng DD. Mining online e-liquid reviews for opinion polarities about e-liquid features. BMC Public Health 2017;17:633. doi: 10.1186/s12889-017-4533-z

4. Yoong SL, Stockings E, Chai LK, Tzelepis F, Wiggers J, Oldmeadow C, Paul C, Peruga A, Kingsland M, Attia J, Wolfenden L. Prevalence of electronic nicotine delivery systems (ENDS) use among youth globally: a systematic review and meta-analysis of country level data. Aust NZ J Public Health 2018;42:303-8. doi: 10.1111/1753-6405.12777
5. Brown CJ, Cheng MC. Electronic cigarettes: product characterization and design consideration. Tob Control 2014;23(Suppl 2):ii4-10. doi: 10.1136/tobaccocontrol- 2013051476

6. Global E-cigarette and T-Vapor Market Report 2018, ID: 4471809 [displayed 15 May 2019]. Available at https://www. researchandmarkets.com/reports/4471809/global-e-cigaretteand-t-vapor-market-analysis

7. Grana RA, Ling PM. "Smoking Revolution" a content analysis of electronic cigarette retail websites. Am J Prev Med 2014;46:395-403. doi: 10.1016/j.amepre.2013.12.010

8. Zhu SH, Sun JY, Bonnevie E, Cummins S, Gamst A, Yin L, Lee M. Four hundred and sixty brands of e-cigarettes and counting: implications for product regulation. Tob Control 2014;23(Suppl 3):iii3-9. doi: 10.1136/tobaccocontrol-2014051670

9. Trehy ML, Ye W, Handwiger ME, Moore TW, Allgire JF, Woodruff JT, Ahadi SS, Black JC, Westenberger BJ. Analysis of electronic cigarette cartridges, refill solutions, and smoke for nicotine and nicotine related impurities. J Liq Chrom Rel Technol 2011;34:1442-58. doi: 10.1080/10826076. 2011.572213

10. Talih S, Balhas Z, Eissenberg T, Salman R, Karaoghlanian N, El Hellani A, Baalbaki R, Saliba N, Shihadeh A. Effects of user puff topography, device voltage, and liquid nicotine concentration on electronic cigarette nicotine yield: measurements and model predictions. Nicotine Tob Res 2015;17:150-7. doi: 10.1093/ntr/ntu174

11. Kosmider L, Sobczak A, Fik M, Knysak J, Zaciera M, Kurek J, Goniewicz ML. Carbonyl compounds in electronic cigarette vapors: effects of nicotine solvent and battery output voltage. Nicotine Tob Res 2014;16:1319-26. doi: 10.1093/ ntr/ntu078

12. Varlet V, Farsalinos K, Augsburger M, Thomas, A, Etter JF. Toxicity assessment of refill liquids for electronic 
cigarettes. Int J Environ Res Public Health 2015;12:4796815. doi: $10.3390 /$ ijerph120504796

13. Pepper JK, EissenbergT.Waterpipes and electronic cigarettes: increasing prevalence and expanding science chemical research. Chem Res Toxicol 2014;27:1336-43. doi: 10.1021/ tx500200j

14. World Health Organization Framework Convention on Tobacco Control.Conference of the Parties to the WHO Framework Convention on Tobacco Control Decision. Moscow, Russian Federation, 13-18 October 2014 [displayed 15 May 2019]. Available at https://apps.who.int/gb/fctc/PDF/ cop6/FCTC_COP6_VR_230115.pdf

15. Directive $2014 / 40 / \overline{E U}$ of the European Parliament and of the Council of 3 April 2014 on the approximation of the laws, regulations and administrative provisions of the Member States concerning the manufacture, presentation and sale of tobacco and related products and repealing Directive 2001/37/EC [displayed 31 May 2019]. Available at https:// eur-lex.europa.eu/legal-content/EN/TXT/ HTML/?uri=CELEX:32014L0040\&from=EN

16. Famele M, Ferranti C, Abenavoli C, Palleschi L, Mancinelli $\mathrm{R}$, Draisci R. The chemical components of electronic cigarette cartridges and refill fluids: review of analytical methods. Nicotine Tob Res 2015;17:271-9. doi: 10.1093/ntr/ntu197

17. Etter JF, Zäther E, Svensson S. Analysis of refill liquids for electronic cigarettes. Addiction 2013;108:1671-9. doi: 10.1111/add. 12235

18. Cameron JM, Howell DN, White JR, Andrenyak DM, Layton ME, Roll JM. Variable and potentially fatal amounts of nicotine in e-cigarette nicotine solutions. Tob Control 2014;23:77-8. doi:10.1136/tobaccocontrol-2012-050604

19. Goniewicz ML, Kuma T, Gawron M, Knysak J, Kosmider L. Nicotine levels in electronic cigarettes. Nicotine Tob Res 2013;15:158-66. doi: 10.1093/ntr/nts103

20. Callahan-Lyon P. Electronic cigarettes: human health effects. Tob Control 2014;23(Suppl 2):ii36-ii40. doi: 10.1136/ tobaccocontrol-2013-051470
21. Czogala J, Goniewicz ML, Fidelus B, Zielinska-Danch W, Travers MJ,Sobczak A. Secondhand exposure to vapors from electronic cigarettes. Nicotine Tob Res 2014;16:655-62. doi: $10.1093 / \mathrm{ntr} / \mathrm{ntt} 203$

22. Schober W, Szendrei K, Matzen W, Osiander-Fuchs H, Heitmann D, Schettgen T, Jörres RA, Fromme H. Use of electronic cigarettes (e-cigarettes) impairs indoor air quality and increases FeNO levels of e-cigarette consumers. Int $\mathrm{J}$ Hyg Environ Health 2013;217:628-37. doi: 10.1016/j. ijheh.2013.11.003

23. Banyasz JL. Chapter 5 . The physical chemistry of nicotine. In: Gorrod JW, Jacob III P, editors. Analytical determination of nicotine and related compounds and their metabolites. Amsterdam: Elsevier Science; 1999. p. 149-90.

24. European Commission. Report from the Commission to the European Parliament and the Council on the potential risks to public health associated with the use of refillable electronic cigarettes, COM (2016) 269 final [displayed 15 May 2019]. Available at https://eur-lex.europa.eu/legal-content/EN/TXT/ $\mathrm{PDF} /$ ?uri=CELEX:52016DC0269\& from $=\mathrm{GA}$

25. Cheng T. Chemical evaluation of electronic cigarettes. Tob Control 2014;23(Supp1 2):ii11-7. doi: 10.1136/ tobaccocontrol-2013-051482

26. Farsalinos KE, Gillman IG, Melvin MS, Paolantonio AR, Gardow WJ, Humphries KE, Voudris V. Nicotine levels and presence of selected tobacco derived toxins in tobacco flavoured electronic cigarette refill liquids. Int J Environ Res Public Health 2015;12:3439-52. doi: 10.3390/ ijerph120403439

27. Kim S, Goniewicz ML, Yu S, Kim B, Gupta R. Variations in label information and nicotine levels in electronic cigarette refill liquids in South Korea: regulation challenges. Int J Environ Res Public Health 2015;12:4859-8. doi: 10.3390/ ijerph120504859

\section{Utvrđeni i deklarirani sadržaj nikotina u tekućinama za punjenje elektroničkih cigareta koje se prodaju u Sjevernoj Makedoniji}

Sve je više korisnika elektroničkih cigareta ili vapinga među makedonskim pušačima, što je izazvalo veliku zabrinutost zbog toksičnosti tekućina i njihovih aerosola, ponajviše zato što razine nikotina u tekućinama za punjenje (e-tekućine) nisu točno ili uopće nisu deklarirane prema aktualnim propisima. Stoga je cilj ovog istraživanja bio odrediti razine nikotina u petnaest uzoraka e-tekućine kupljenih u specijaliziranim prodavaonicama u Makedoniji primjenom plinske kromatografije. Koncentracije nikotina odstupaju od deklaracija proizvođača u devet od dvanaest uzoraka: u pet su veće i u četirima manje od deklariranih, u rasponu od $-16,7 \%$ do $+30,0 \%$. Ove značajne razlike između stvarnih i deklariranih koncentracija nikotina u analiziranim e-tekućinama zahtijevaju veću pozornost zdravstvenih i regulativnih tijela. 